Georg Holzer:

\title{
Untersuchungen zum Urslavischen: Einleitende Kapitel, Lautlehre, Morphematik.
}

Berlin: Peter Lang. 2020. 257 s. Schriften über Sprachen und Texte 13.

ISBN 978-3-631-81663-9

Recenzovaná kniha přináší dosud nejucelenější představení toho pojetí rekonstrukce slovanského prajazyka, které dlouhodobě buduje Georg Holzer a v posledních letech v různých aspektech aplikuje i řada jeho následovníků (srov. kupř́kladu SKACH 2015 pro materiál z řeckého prostoru, nejvýrazněji KLOTz 2017 v podobě souhrnu slovní zásoby, nejnověji pak LESCHBER 2021 pro otázku nejstarších slovanských výpůjček v rumunštině). Autor zde shrnul, precizoval a dále rozvinul výsledky mnoha svých starších prací: seznam v knize citované literatury obsahuje téměř 70 článků a knih s Holzerovým autorstvím či spoluautorstvím, publikovaných od roku 1980 (o jednom knižním titulu, zaměřeném specificky na vývoj z praslovanštiny do chorvatštiny a kontakt s místním románským dialektem, jsme před časem referovali i v tomto časopise, srov. BočEK 2008). Kniha obsahuje popis praslovanského hláskosloví a slovotvorné morfematiky, zatímco zpracování syntaxe autor v předmluvě anoncuje jako svazek, který by měl následovat, a pro praslovanskou slovní zásobu a flekční morfologii odkazuje na již vydaný slovník Klotzův včetně jeho úvodních kapitol.

V prvních třech kapitolách Holzer resumuje svoje pojetí praslovanštiny. Nejprve (str. 17-20) objasňuje způsob záznamu praslovanských forem. Autor užívá originálního zápisu praslovanštiny, který má co nejvíce odpovídat předpokládanému reálnému znění (Reallautung) tohoto jazyka. S tradiční podobou zápisu pracuje jen s jako pomocným, čistě konvenčním pojmenováním (Nennlautung). Např́iklad namísto psl. *şðorvъ se tedy v tomto modelu rekonstruuje tvar *sudar'wu. V tomto ohledu následuje Holzer několik starších prací jiných autorů, ale pracuje takto soustavněji a s daleko obsáhlejším materiálem a jeho specifickým přínosem je důsledná práce i se suprasegmentálními jevy. Následně (s. 21-41) autor přibližuje, jakou fázi vlastně praslovanština (Urslavisch) v jeho pojetí představuje: je to stav zhruba k roku 600 po Kristu, tedy stadium víceméně bezprostředně po slovanské expanzi. Jedná se o dobu přechodu mezi antikou a středověkem, kdy jsou nositelé tohoto jazyka již zaznamenáni v písemných pramenech. Holzer zde podává užitečný přehled dokladů v latinských a byzantských pramenech, informujících o řadě sociálních a sociolingvistických aspektů. Krátce tematizuje také následnou roli slovanského jazyka v avarské říši jako lingua franca, tedy úlohu společného dorozumívacího jazyka mezi Slovany a jinými etniky (nejen Avary, ale i Gepidy či románským obyvatelstvem), k čemuž měly přispět už některé rysy praslovanštiny, zejména její jednoduchost, a tedy snadná naučitelnost. Konečně (str. 43-48) pak autor ještě konkretizuje, při jakých metodologických postojích a jakým empirickým materiálem je obhajitelná a doložitelná jednotnost praslovanštiny.

1 Publikace vznikla s podporou dlouhodobého koncepčního rozvoje Ústavu pro jazyk český AV ČR, v. v. i., RVO: 68378092 . 
Jádrem knihy jsou pak dvě kapitoly věnované praslovanskému hláskosloví a morfematice, přičemž v obou případech Holzer na př́slušných místech zmiňuje a komentuje případné změny svého výkladu oproti starším textům, čímž čtenáři umožňuje sledovat i vývoj tohoto modelu praslovanštiny.

V kapitole přinášející popis hláskosloví (Lautlehre, s. 49-119) autor na rozsáhlém počtu domácích slov, ale i výpůjček z jiných jazyků na slovanskou půdu či naopak odtud do jiných jazyků ukazuje fonetický stav praslovanštiny. Činí tak jednak v sérii 28 dílčích kapitol, z nichž každá je věnována jedné popraslovanské změně (jedná se o změny chápané v tradičním pojetí jako pozdněpraslovanské, např. druhá a třetí palatalizace, přehlásky, monoftongizace, $\bar{u}>\bar{y}, a>0$, vznik jerů atd.), jednak v souhrnném glosáři výpůjček uváděných již v předchozím výkladu (materiál především románský a germánský, ale i albánský, řecký, baltský, ugrofinský, íránský a „staroevropský“). Z takto uvedeného vývoje domácích slov a z hláskových substitucí u výpůjček je vyvozen praslovanský stav vokalismu, konsonantismu i suprasegmentálních jevů. Jedná se přitom o synchronní analýzu praslovanštiny k zmíněnému období kolem roku 600: jednotlivé popraslovanské změny nejsou představovány v jejich relativní chronologii, ale konstatuje se jednoduše, že v praslovanštině ještě neprobíhaly; výpůjčky jsou řazeny abecedně napříc časem i přijímajícími a zdrojovými jazyky.

Kapitola o praslovanské morfematice (Morphematik, s. 121-226) obsahuje to, co Holzer dř́ve nazýval morfofonologií. Je to synchronní popis abstraktní roviny, jež obsahuje všechny druhy morfémů (kořenové, afixální, koncovkové) a jež je v daném stavu jazyka neproměnná (změna by představovala diachronní restrukturaci do jiného stavu) a prostá variantnosti. Tato rovina je již výsledkem proběhlé slovotvorby (obsahuje tedy celá slova) a zároveň sama představuje východisko pro fonetickou realizaci (a tato je pak zase východiskem pro fonologii $\mathrm{v}$ tradičním smyslu). Přechod od hloubkové (morfematické) struktury k povrchové (fonetické) manifestaci popisuje autor generativně, pomocí řady transformačních pravidel, jimiž se z morfémů odvozují jejich kontextově podmíněné realizace, (alo)morfy. Holzer zde zavádí ještě třetí typ zápisu praslovanských slov, a to právě morfematický (do modelu by fakticky patřil i zápis fonologický, od kterého se však v práci odhlíží). Záznam transformačního procesu pak vypadá např́klad takto: ${ }^{\circ} \underline{b} \underline{u} k|\underline{\underline{\imath}} n| \underline{a} \cdot$ (morfematický zápis včetně vyznačení hranic

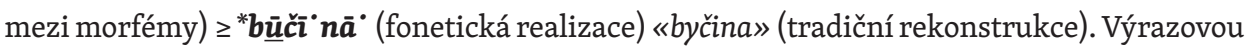
jednotu na rovině morfematické umožňuje a zajištuje předpoklad a konstrukce 21 nestálých („flüchtige“) segmentů, tj. prvků, které při transformaci způsobí proměnu morfémů v konkrétní

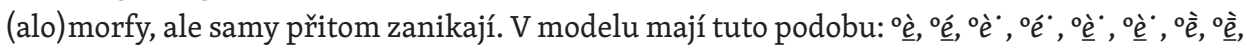

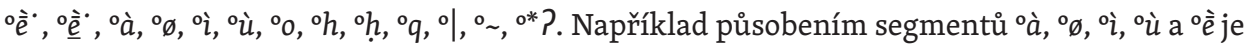
popsatelný vznik jednotlivých ablautových stupňů v kořenových morfémech, ํㅐ, ำ a oq mají na svědomí pohyby př́izvuku atd. Transformačních pravidel je v Holzerově modelu 23, z nich šesti se účastní právě nestálé segmenty. Jinak zde nacházíme povětšinou transformace, jejichž příčinou je některá předpraslovanská hlásková změna. Tímto modelem pak autor popisuje chování jednotlivých druhů morfémů a vysvětluje jednotlivé morfematické jevy: probírají se akcentuační paradigmata, chování proklitik, enklitik a anaklitik, jevy jako univerbizace, reduplikace, analogie apod. Na závěr jsou připojeny souhrnné poznámky k jednotlivým sufixům. 
Poslední, krátká kapitola (str. 227-233) přináší další poznámky k jednotlivým praslovanským a popraslovanským slovům, zejména bibliografické: víceméně se jedná o výběrové uvedení další literatury, v níž se o slovech pojednává. Knihu pak uzavírá seznam literatury (str. 235-257).

Jak vyplývá z našeho představení recenzované práce, Holzerovo pojetí praslovanštiny vykazuje celou řadu specifik. $Z$ hlediska saussurovské „,nněǰ̌i lingvistiky“ je pozoruhodné především to, že autor prajazyk nelokalizuje, jak by snad tradicionalisticky laděný srovnávací lingvista očekával, do pravlasti. Jazyku v pravlasti, předpokládané autorem $v$ tradičním duchu v oblastech na sever od Karpat, vyhrazuje Holzer př́zvisko předpraslovanština (Vorurslavisch) a počitá u něj s existencí nářečních rozdílů, jež měly být následně setřeny během slovanské expanze. S touto otázkou pak souvisí i koncept slovanského jazyka fungujícího jako lingua franca, jenž byl či je zastávaný vedle Holzera i dalšími autory, ovšem s různými odlišnostmi (datace, geografické rozšiření, vztah k slovanské etnicitě, způsob zformování takto fungujícího jazyka). Této otázce jsme se detailně věnovali již dříve (BočEK 2014, 49-104) a přednesli řadu kritických připomínek $\mathrm{k}$ jednotlivým pojetím. Dnes bychom $\mathrm{k}$ tomu nabídli alespoň následující stručnou úvahu. Zastávaný předpoklad jednoduchosti a zejména jednotnosti jazyka, který se má stát lingvou frankou (srov. u Holzera s. 47: „eine uneinheitliche Sprache taugt nicht recht zur lingua franca“), se nám nezdá být nutnou podmínkou. Jednoduchým se jazyk může ad hoc stávat právě jen ve specifické komunikační situaci (hovor k „,izinci“ čili sociolingvistickým slovníkem foreigner talk), ale je přitom dobře myslitelné, že v jiných komunikačních situacích užívají rodilí mluvčí svůj jazyk nadále v nezjednodušené a napřič societou i nejednotné, nejen teritoriálně, ale třeba i sociálně rozrůzněné podobě (srov. dnešní fungování angličtiny jako lingua franca versus její užívání rodilými mluvčími mezi sebou). Synchronní rekonstrukci prajazyka v jednotné podobě takový předpoklad nemusí vadit, i při synchronním popisu doložených jazyků se zpravidla od variantnosti tak či onak odhlíží (popisuje se abstraktní systém konkrétního spisovného jazyka, dialektu). Že se jazyk užívaný jako lingua franca stane jednoduchým (třeba proto, že se rozšíŕí jeho „cizinci“ nedokonale osvojená varianta čili L2, s př́padným zánikem jejich L1), je až sekundární záležitost. Pokud jde o jednotnost praslovanštiny, je rovněž možno připomenout, že autorem představená rekonstrukce praslovanštiny představuje vlastně rekonstrukci dvojího typu: u fonetiky se jedná - pro jednou řečeno strukturalisticky - o rekonstrukci parole, přičemž zde logika historicko-srovnávací metody skutečně vede $\mathrm{k}$ výslovnostní jednotě jednotlivých forem vyvozených $\mathrm{z}$ různosti forem doložených ve slovanských jazycích; u morfematiky jde o rekonstrukci jednotnosti v langue (morfémů), ale přidruženě se zároveň ukazuje realizační nejednotnost v parole (alomorfy). Lakonicky řečeno: „cizinci“ se setkávali s praslovanský-

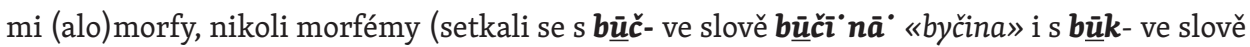
bū $k \boldsymbol{u}$ «bykъ»). To, že byla tato alomorfie menší ve srovnání s pozdějšími fázemi jazyka, je pak otázkou míry.

Sílu Holzerova modelu spatřujeme především v čistě jazykových rozborech, kdy popisy jednotlivých oblastí jazyka (abstrakce staršího stavu z pozdějších hláskových změn, striktní hláskové substituce, transformační pravidla generující z morfémů alomorfy) připomínají 
dobře sestrojené a promazané stroje, které nikde nezadrhávají a jimiž je možné téměř automaticky zpracovat dostupný slovanský materiál dosahující časově do takto pojímaného praslovanského období. Zdá se nám, že takto konzistentní popis dosud nikdo nepředložil.

\section{LITERATURA}

BočEK, Vít. 2008. [recenze] Georg Holzer: Historische Grammatik des Kroatischen. Einleitung und Lautgeschichte der Standardsprache. Frankfurt am Main: Peter Lang 2007. Linguistica Brunensia A 56, 268-271.

BočEK, Vít. 2014. Praslovanština a jazykový kontakt. Praha: Nakladatelství Lidové noviny.

KLOTZ, Emanuel. 2017. Urslawisches Wörterbuch. Wien: Facultas.

LESCHBER, Corinna. 2021. Urslavische Lexik in Rumänischen. In: JourAveL, Anna - MATHys, Audrey, eds. Wort- und Formenvielfalt. Festschrift für Christoph Koch zum 80. Geburtstag. Berlin: Peter Lang, 207-218.

SKACH, Elisabeth. 2015. Die Lautgeschichte des Mittelalterlichen Slavischen in Griechenland. Frankfurt am Main: Peter Lang.

\section{Vít Boček}

Czech Language Institute of the CAS, v. v. i.

Veveř́ 97, 602 oo Brno

Czech Republic

vitbocek@gmail.com 